\title{
Article \\ Continuous Cooling Transformation Behaviour and Bainite Transformation Kinetics of 23CrNi3Mo Carburised Steel
}

\author{
Wenjun Song ${ }^{1,2}$, Min Lei ${ }^{1,2, *}$, Mingpan Wan ${ }^{1,2}$ and Chaowen Huang ${ }^{1,2}$ \\ 1 College of Materials and Metallurgy, Guizhou University, Guiyang 550025, China; swj186855@163.com (W.S.); \\ mpwan@gzu.edu.cn (M.W.); cwhuang@gzu.edu.cn (C.H.) \\ 2 Key Laboratory for Materials Structure and Strength of Guizhou Province, Guiyang 550025, China \\ * Correspondence: mlei1@gzu.edu.cn; Tel.: +86-156-8517-2816
}

Citation: Song, W.; Lei, M.; Wan, M.;

Huang, C. Continuous Cooling Transformation Behaviour and Bainite Transformation Kinetics of 23CrNi3Mo Carburised Steel. Metals 2021, 11, 48. https://doi.org/ 10.3390/met11010048

Received: 3 December 2020

Accepted: 24 December 2020

Published: 28 December 2020

Publisher's Note: MDPI stays neutral with regard to jurisdictional claims in published maps and institutional affiliations.

Copyright: () 2020 by the authors. Licensee MDPI, Basel, Switzerland. This article is an open access article distributed under the terms and conditions of the Creative Commons Attribution (CC BY) license (https: / / creativecommons.org/ licenses/by/4.0/).

\begin{abstract}
In this study, the phase transformation behaviour of the carburised layer and the matrix of 23CrNi3Mo steel was comparatively investigated by constructing continuous cooling transformation (CCT) diagram, determining the volume fraction of retained austenite (RA) and plotting dilatometric curves. The results indicated that Austenite formation start temperature (Ac1) and Austenite formation finish temperature (Ac3) of the carburised layer decreased compared to the matrix, and the critical cooling rate $\left(0.05^{\circ} \mathrm{C} / \mathrm{s}\right)$ of martensite transformation is significantly lower than that $\left(0.8^{\circ} \mathrm{C} / \mathrm{s}\right)$ of the matrix. The main products of phase transformation in both the carburised layer and the matrix were martensite and bainite microstructures. Moreover, an increase in carbon content resulted in the formation of lamellar martensite in the carburised layer, whereas the martensite in the matrix was still lath. Furthermore, the volume fraction of RA in the carburised layer was higher than that in the matrix. Moreover, the bainite transformation kinetics of the $23 \mathrm{CrNi3Mo} \mathrm{steel} \mathrm{matrix} \mathrm{during}$ the continuous cooling process indicated that the mian mechanism of bainite transformation of the 23CrNi3Mo steel matrix is two-dimensional growth and one-dimensional growth.
\end{abstract}

Keywords: 23CrNi3Mo steel; carburised layer; dilatometric curve; bainite transformation kinetics; transformation behavior

\section{Introduction}

$23 \mathrm{CrNi3Mo}$ steel, which is widely used to make hollow drill rods, is a kind of $\mathrm{Cr}-\mathrm{Ni}-$ Mo series low-carbon alloy steel [1]. For example, the composition of drill steel utilized by the internationally renowned drill tool brands Sandvik and Atlas is consistent with that of 23CrNi3Mo steel [2]. Cr-Ni-Mo series low-carbon alloy steel has generated interest from drilling tool practitioners and scholars [3-5]. Economic and environmental factors necessitate that the service lifetime of machine components and structures are prolonged and extended. Accordingly, various surface engineering techniques that can endow additional useful surface properties, such as high strength and wear resistance, have been devised to meet this demand [6]. Among these techniques, carburizing heat treatment is one of the most widely applied to improve steel hardness and strength [7-9].

Current research on carburizing heat treatment focuses on the heat treatment process after carburizing [5,9-11]. The influence of thermal deformation and cold working on the phase transition of materials is enthusiastic by scholars [12,13], as a conventional chemical heat treatment method, the effect of carburizing on the phase transition of the material should also be taken seriously, just like thermal deformation and cold working, etc. This is due to Several material transformation behaviours must be explored prior to further processing and heat treatment. Theoretical continuous cooling transformation (CCT) is important in exploring material transition behaviours because it can provide the optimal combination of time-temperature-cooling rate to predict the ideal start of phase transition. Yan [4] researched the gradient microstructure of 23CrNi3Mo carburised steel under different cooling rates $\left(0.05-3{ }^{\circ} \mathrm{C} / \mathrm{s}\right)$ and indicated that when continuous 
cooling, microstructure of the carburized Layer is martensite; when the cooling rate is $0.05-0.1^{\circ} \mathrm{C} / \mathrm{s}$, the microstructure of the core is lower bainite, and the microstructure of the transition region is a mixed structure of martensite + lower bainite; when the cooling rate range from $0.1^{\circ} \mathrm{C} / \mathrm{s}$ to $1^{\circ} \mathrm{C} / \mathrm{s}$, the microstructure of transition area is martensite and the microstructure of the core is a mixed microstructure of martensite + lower bainite; when the cooling rate $\geq 3{ }^{\circ} \mathrm{C} / \mathrm{s}$, the microstructure of the transition area and the core are martensite. Jiang et al. [5,9] summarized the microstructure transformation of the carburizing steel $(25 \mathrm{Si} 2 \mathrm{MnCrNi} 2 \mathrm{MoV}, 23 \mathrm{CrNi} 3 \mathrm{Mo})$, at the cooling rate $\left(0.05-5^{\circ} \mathrm{C} / \mathrm{s}\right)$, the transformed microstructure from the surface to the position nearly $1.0 \mathrm{~mm}$ are all high carbon martensite. The microstructures at the transition zone and the matrix change with the cooling rate. The microstructure consists of martensite and bainite $\left(0.05-0.3^{\circ} \mathrm{C} / \mathrm{s}\right)$, while the cooling rate is high than $0.3^{\circ} \mathrm{C} / \mathrm{s}$, only martensite exists. The network carbide was formed along the boundary in the microstructure at the surface when the cooling rate range from $0.05-3{ }^{\circ} \mathrm{C} / \mathrm{s}$. However, the usual approach in studying transformation behaviour after carburizing is treating the carburised layer (the surface) and the matrix (the core) as a whole. This method can conveniently regulate the gradient microstructure formed by carbon content gradient. However, they failed to treat the carburised layer and the matrix as two single entities in observing phase transformation characteristics.

In this work, the phase transformation behaviours of a carburised layer and a $23 \mathrm{CrNi} 3 \mathrm{Mo}$ steel matrix were investigated. The carburised layer and the matrix were processed as two separate specimens. This study aimed to obtain deeper phase transformation data of the carburised layer and the matrix during continuous cooling. The results provide a reference for exploring the mechanism of heat treatment process after carburizing.

\section{Materials and Methods}

The chemical compositions of the alloy are listed in Table 1.

Table 1. Chemical composition of the tested steel (wt. \%).

\begin{tabular}{ccccccccc}
\hline $\mathbf{C}$ & $\mathbf{S i}$ & $\mathbf{M n}$ & $\mathbf{C r}$ & $\mathbf{N i}$ & $\mathbf{M o}$ & $\mathbf{P}$ & $\mathbf{S}$ & $\mathbf{F e}$ \\
\hline 0.23 & 0.29 & 0.65 & 1.29 & 2.87 & 0.22 & 0.001 & 0.013 & Bal. \\
\hline
\end{tabular}

Specimens were cut via electrical discharge machining into cylinders of $4 \mathrm{~mm}$ in diameter and $10 \mathrm{~mm}$ in length. The continuous transformation behaviour of the carburised layer was evaluated by carburizing some of the specimens. The surface of carburised specimens was peeled off by $0.4 \mathrm{~mm}$, and carbon content was measured using a carbonsulphur spectrometer (LECOCS844, LECO, Michigan, MI, USA). The schematic of the quartz push rod and sample (Figure 1a). During the experiment, the part in contact with and measured by the quartz push rod was an outer ring with a thickness of $0.4 \mathrm{~mm}$. The carbon content of the outer ring after carburisation was $0.73 \%$ (Figure $1 \mathrm{~b}$ ), which is similar to that reported in the literature $[9,11,14]$.

The Ac1 and Ac3 of the steel were measured using a DIL402C dilatometer (Netzsch, Selb, Germany). Dilatometric curves were tested on a DIL805A/D dilatometer (Netzsch, Selb, Germany). The specimens were heated up to $920^{\circ} \mathrm{C}$ at a rate $80{ }^{\circ} \mathrm{C} / \mathrm{s}$ for $15 \mathrm{~min}$. Subsequently, the specimens were continuously cooled to room temperature at a rate of $0.02,0.03,0.05,0.08,0.1,0.2,0.4,0.8,1,3,5$ and $15^{\circ} \mathrm{C} / \mathrm{s}$. The hardness was tested using a Vickers tester model HVS-1000 under an applied load of $9.8 \mathrm{~N}$ for $10 \mathrm{~s}$, Specimens for metallographic examination were mechanically polished and etched with $4 \%$ nitric acid alcohol solution and analysed via OM and scanning electron microscopy (SEM, Zeiss SUPRA-40, Oberkochen, Germany). The volume fraction of retained austenite (RA) was determined using an X-350 stress tester (AST, Handan, China). 

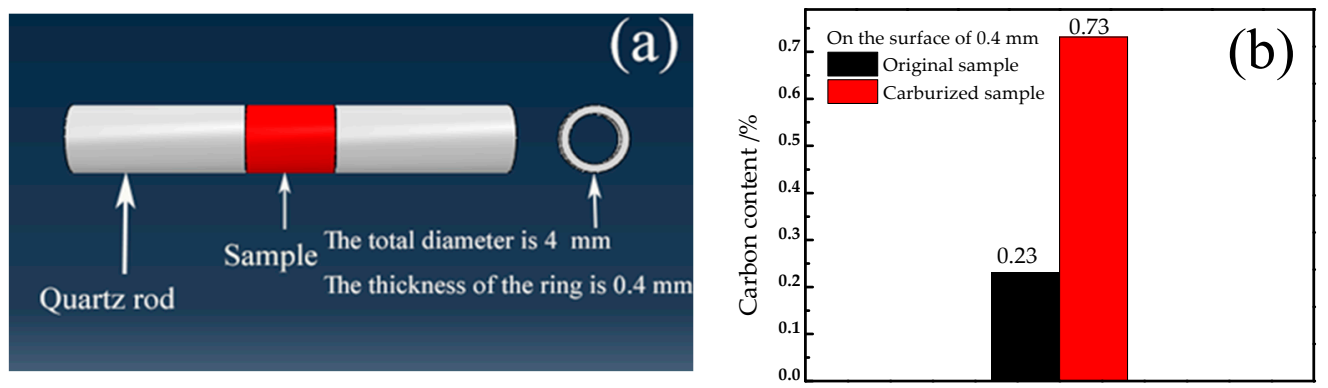

Figure 1. (a) Quartz push-rod diagram, (b) carbon content of the carburised sample and the original sample.

\section{Experimental Results and Analysis}

\subsection{Differences in Dilatometric Curves between the Carburised Layer and the Matrix}

As shown in Figure 2, the dilatometric curves of both the carburised layer and the matrix exhibited different characteristics. The dilatometric curves of the samples cooled at the rates of $3{ }^{\circ} \mathrm{C} / \mathrm{s}$ and $5{ }^{\circ} \mathrm{C} / \mathrm{s}$ were analysed to explain these differences.
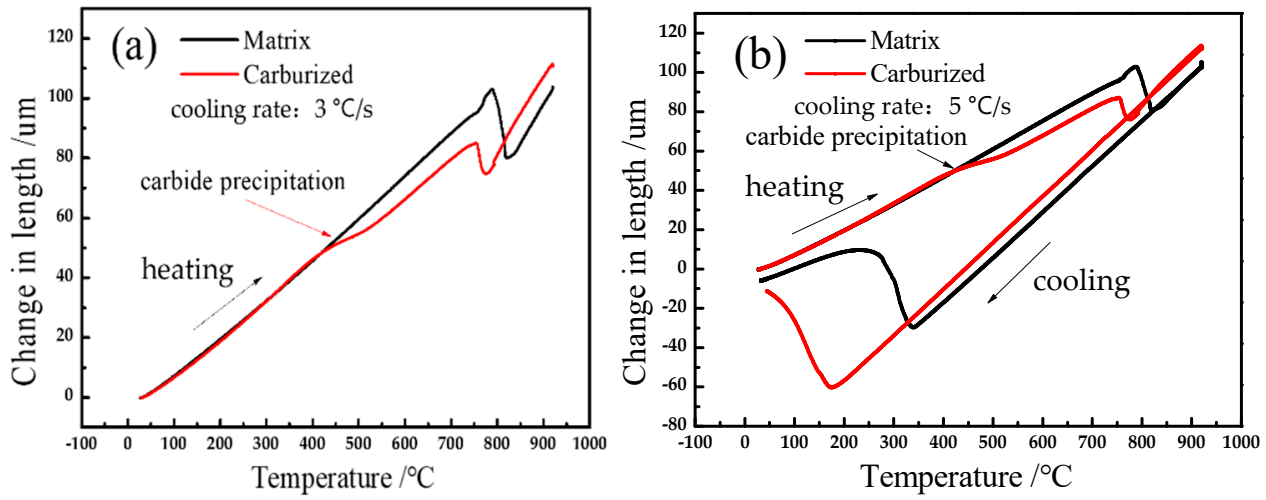

Figure 2. (a) Dilatometric curves of the carburised layer and the matrix at the heating stage, (b) dilatometric curve of the carburised layer and the matrix.

The dilatometric curves of both the carburised layer and the matrix during the heating stage are plotted in Figure 2a. Their dilatometric curves coincided in the early heating stage, and volume increased as temperature increased. The radial change of the specimens at this stage was approximately linear. As temperature increased to $470{ }^{\circ} \mathrm{C}$, the dilatometric curve of the carburised layer showed a nonlinear change. As temperature decreased from $920^{\circ} \mathrm{C}$ to about $340{ }^{\circ} \mathrm{C}$, a similar linear contraction behaviour was observed in both curves, and they showed similar length changes (Figure $2 b$ ). The contraction in the two curves reversed with further cooling. The dilatometric curve sharply turned because the volume expansion caused by martensitic transformation was considerably larger than the volumetric shrinkage caused by the decrease in temperature [15].

Carbide precipitation is beneficial to reduce the degree of lattice distortion, such modifications affect the expansion coefficient of alloys. When the volumes of carbide precipitation are small, it difficult to observe whether the expansion coefficient of the alloy had changed by the dilatometric curve. As shown in Figure 3a, the carbide precipitation in the matrix has a certain orientation, part of the carbide forms a certain angle with the ferrite, and the rest is in a parallel relationship with the ferrite. Figure $3 b$ indicated that the high carbon content makes the carbide precipitation in the carburized layer during the heating stage was stronger than that in the matrix, large amounts of carbide precipitates resulted in nonlinear changes in the dilatometric curve of the carburised layer. During the cooling stage, the difference in carbon content of the carburised layer and the matrix led to the difference in their dilatometric curves by affecting phase transition. The increase in 
carbon content reduced the starting temperature of martensitic transformation (Ms) of the carburised layer.
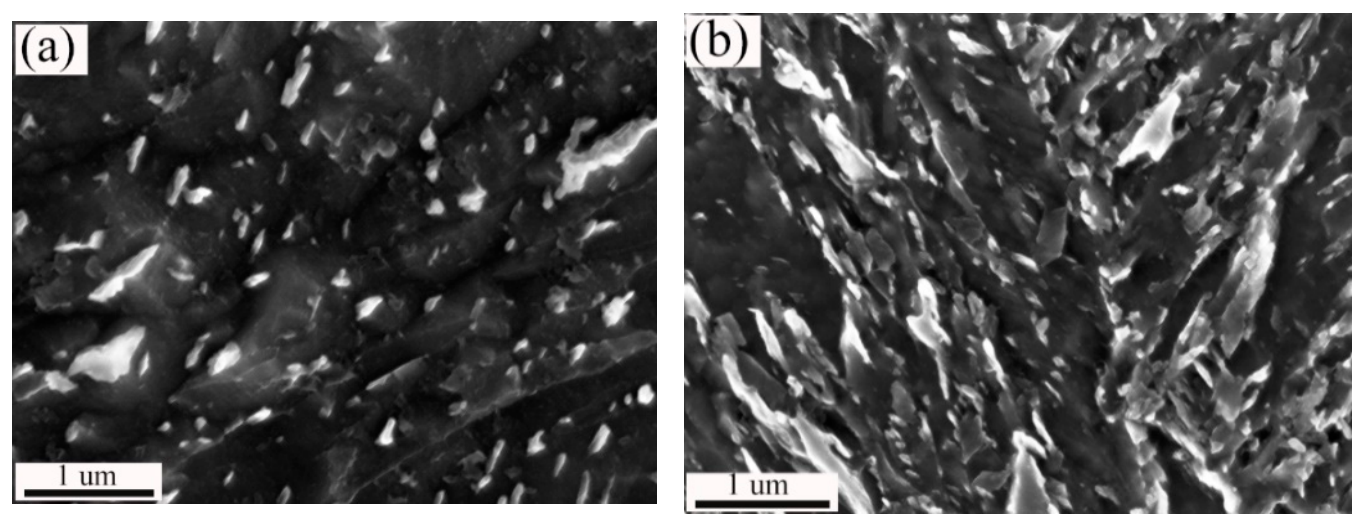

Figure 3. SEM micrographs of the matrix, (a) and the carburised layer, (b) heated to $550{ }^{\circ} \mathrm{C}$ and quickly cooled $\left(15^{\circ} \mathrm{C} / \mathrm{s}\right)$ to room temperature.

\subsection{Microstructural Analysis}

According to the steel's undercooled austenite transformation temperature range and transformation characteristics, and the microstructure and mechanical properties of the transformation products, the undercooled austenite transformation is divided into pearlite transformation, bainite transformation and martensite transformation. The pearlite transformation is a diffusion-type phase transition, which is usually carried out under the conditions of high temperature and slow cooling rate, this is because it requires sufficient diffusion of atoms (iron atoms, carbon atoms) to occur. Bainite transformation is often referred to as mid-temperature transition. In the bainite transformation temperature range, it is difficult for iron atoms to diffuse, while carbon atoms can continue to diffuse. As the cooling rate increases and the temperature decreases, a third type of phase transition will occur, which is completely different from pearlite transformation and bainite transformation. This non-diffusion coherent shear transition is named martensite transformation. Combining the dilatometric curve, microstructure and hardness to determine the type of phase transition is a common method.

\subsubsection{Microstructures of the Carburised Layer}

The typical cooling curves of the carburised layer and their corresponding microstructures are displayed in Figures 4 and 5. The hardness curves of the matrix and the carburised layer at different cooling rates are plotted in Figure 10.

At a very slow cooling rate $\left(0.02{ }^{\circ} \mathrm{C} / \mathrm{s}\right)$, a mixed microstructure of bainite, martensite and pearlite were achieved (Figure 4a). An enlarged view of bainite in Figure 4a is shown in Figure 4f, which shows that the characteristic microstructures of lamellar bainite and martensite was black fine needle. The massive black structure observed in Figure 4a was pearlite, according to the SEM micrograph in Figure 4e, this structure was a layered complex composed of alternately stacked thin layers of ferrite and cementite. Although the pearlite was observed in the microstructure, there is no signal of pearlite transformation on the cooling curve. This is because the specific volume of pearlite is small, and the quantity of the pearlite transformation is less. When the cooling rate increase to $0.05^{\circ} \mathrm{C} / \mathrm{s}$, the transformation start temperature turned to $190^{\circ} \mathrm{C}$ (Figure $5 \mathrm{~b}$ ), and the microstructure exhibited the trait of lamellar martensite (Figure $4 \mathrm{~b}$ ). As the cooling rate further increased, only exists martensite microstructure and became finer (Figure $4 \mathrm{c}, \mathrm{d}$ ), also the Ms point decrease with the cooling rate increase, the phase transformation driving force increase caused by the cooling rate increase is responsible for the both changes. Pay attention to $0.02{ }^{\circ} \mathrm{C} / \mathrm{s}$, the Ms point $\left(155^{\circ} \mathrm{C}\right)$ substantially decreased because bainite transformation occurred. During bainite transformation, carbon atoms must redistribute in austenite by 
diffusion to form carbon-rich and carbon-poor regions to meet the carbon content required for the nucleation of the new phase. After bainite transformation, part of the untransformed austenite is transformed into martensite in the subsequent cooling process. However, as carbon content increases, the Ms point decreases. As mentioned above, the observed microstructures corresponded well with the results of dilatometry and hardness tests, and conclude that the critical cooling rate of martensite transformation is $0.05^{\circ} \mathrm{C} / \mathrm{s}$.
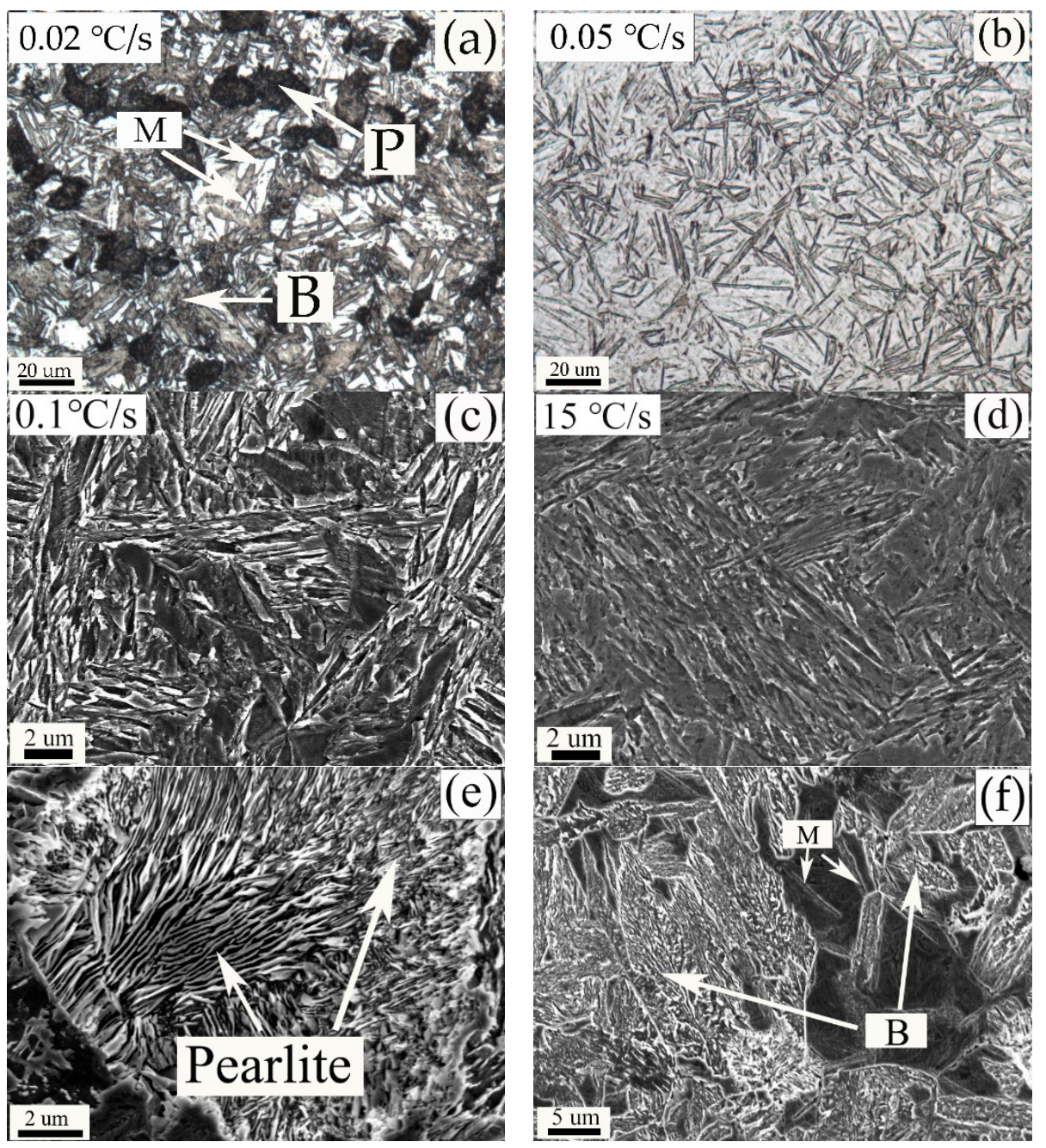

Figure 4. (a-d) Microstructures of the cooling rate of $0.02,0.05,0.1$ and $15^{\circ} \mathrm{C} / \mathrm{s}$. (e) An enlarged view of pearlite in $(\mathbf{a}, \mathbf{f})$ An enlarged view of bainite and martensite in $(\mathbf{a})$.
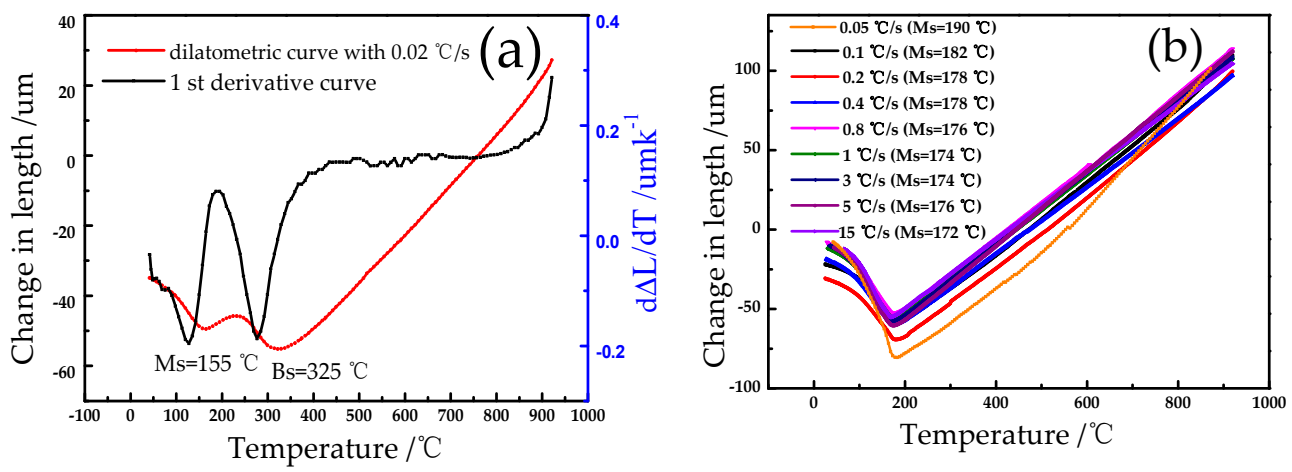

Figure 5. (a) The dilatometric curve of the carburised layer at a cooling rate of $0.02{ }^{\circ} \mathrm{C} / \mathrm{s}$. (b) The dilatometric curve of the carburised layer at the cooling rate range of $0.05-15^{\circ} \mathrm{C} / \mathrm{s}$. 


\subsubsection{Microstructures of the Matrix}

Under different cooling rates, the transformation product of austenite changed to ferrite + granular bainite $\rightarrow$ granular bainite + lath martensite $\rightarrow$ lath martensite.

As can be observed from the SEM micrograph in Figure 6a, the microstructure was granular bainite, and some small island particles were distributed in the massive ferrite. As shown in Figure $7 \mathrm{a}$, at about $646^{\circ} \mathrm{C}$, a knee point was observed in the dilatometric curve of $0.02{ }^{\circ} \mathrm{C} / \mathrm{s}$, indicating that the ferrite formed before bainite transformation. As shown in Figure $7 \mathrm{~b}$, within the cooling rate range of $0.1-15^{\circ} \mathrm{C} / \mathrm{s}$, the dilatometric curves showed a similar contraction feature, and both martensite and bainite transformations displayed a similar temperature characteristic, in terms of the phase transition starting temperature.

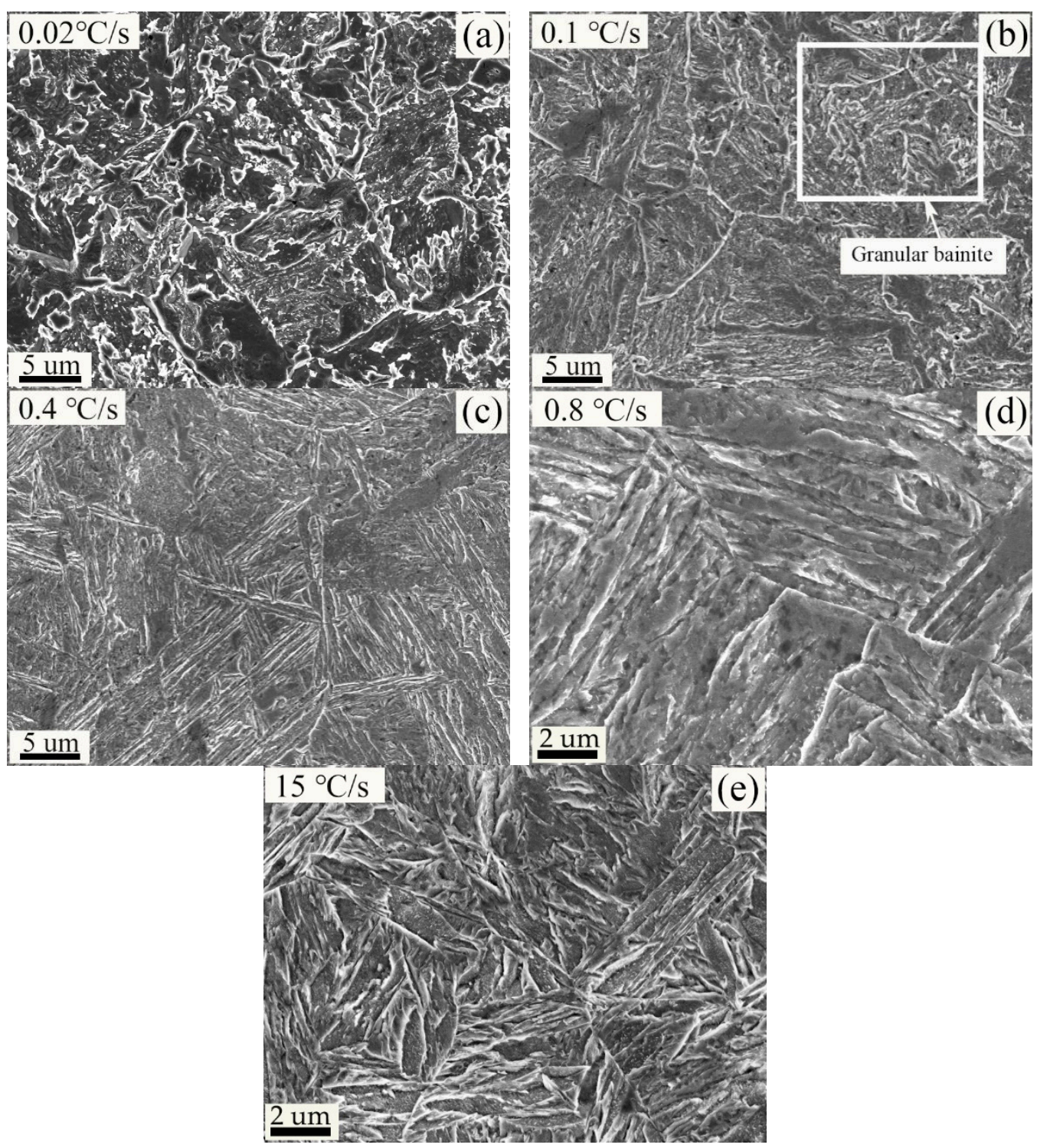

Figure 6. SEM micrograph of the matrix at the cooling rate of $0.02{ }^{\circ} \mathrm{C} / \mathrm{s}(\mathbf{a}), 0.1^{\circ} \mathrm{C} / \mathrm{s}(\mathbf{b}), 0.4{ }^{\circ} \mathrm{C} / \mathrm{s}(\mathbf{c})$, $0.8^{\circ} \mathrm{C} / \mathrm{s}(\mathbf{d})$ and $15^{\circ} \mathrm{C} / \mathrm{s}(\mathbf{e})$. 

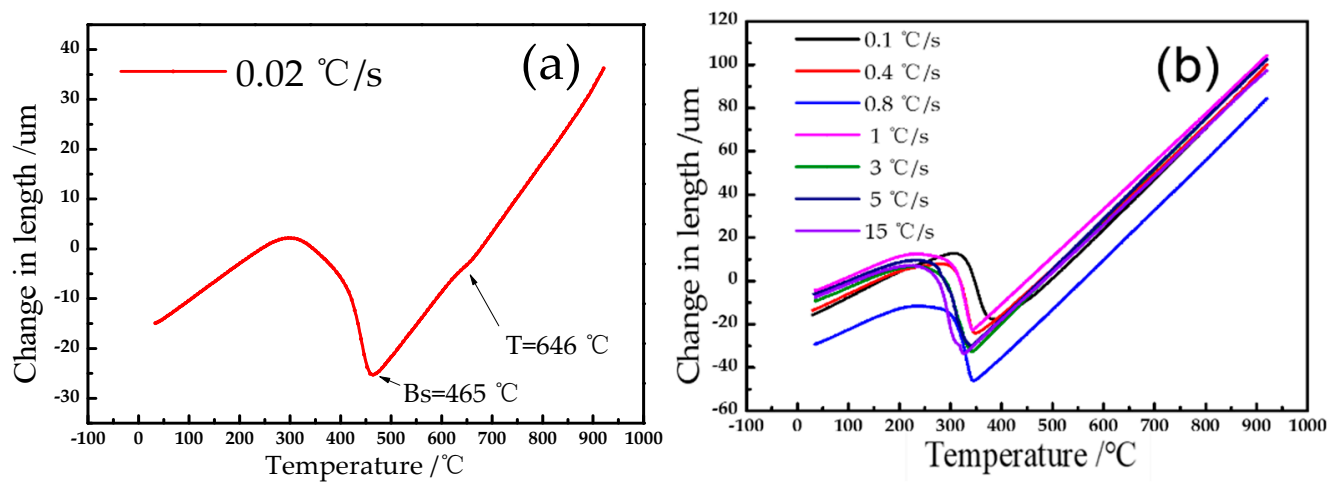

Figure 7. The dilatometric curves of the matrix when the cooling rate at $0.02{ }^{\circ} \mathrm{C} / \mathrm{s}$ (a) and range from $0.1{ }^{\circ} \mathrm{C} / \mathrm{s}$ to $15^{\circ} \mathrm{C} / \mathrm{s}(\mathbf{b})$.

The formation of granular bainite is associated with high temperature, slow cooling rates, high carbon activity gradients and high carbon diffusion rates. These factors lead to the appearance of carbon-poor and carbon-rich regions in the parent austenite before bainitic transformation occurs. When temperature decreases within the moderate range of bainite, ferrite nucleates in the carbon-poor regions and grows separately. As ferrites grow, meet and merge with each other, a ferrite matrix is then formed. Consequently, the area of carbon-rich austenite among massive ferrite gradually reduces, resulting in numerous isolated islands of the carbon-rich austenite. The shape and dimension of the carbon-rich austenite islands depend on the growth of massive ferrite around. Therefore, the shape and dimension tend to be irregular. In the subsequent cooling process, the chemical driving force for the transformation increases as temperature decreases. The islands of the carbonrich austenite mainly decompose into ferrite and cementite and retains a small amount of RA [16].

As the cooling rate reached $0.1^{\circ} \mathrm{C} / \mathrm{s}$, the microstructure turned to a mixture of lath martensite and granular bainite (Figure $6 \mathrm{~b}$ ). As the cooling rate further increased to $0.4{ }^{\circ} \mathrm{C} / \mathrm{s}$, the trait of the lath martensite became quite obvious (Figure $6 \mathrm{c}$ ). When the cooling rate reached $0.8^{\circ} \mathrm{C} / \mathrm{s}$, the hardness curve of the matrix had a step growth (Figure 10), and only martensite existed in the microstructure (Figure 6d). Follow the cooling rate further increased, the hardness $(490 \mathrm{HV})$ and microstructure no longer remarkably changed. Therefore, $0.8^{\circ} \mathrm{C} / \mathrm{s}$ was determined to be the critical cooling rate for martensitic transformation. Figure 8 indicated that the martensite of the carburised layer was finer than that of the matrix, this is in agreement with other results described in the literature [17]. The differences in microstructure morphology were attributed to differences in carbon content, resulting in different volumetric strain energies. Moreover, the rectangularity of martensite increases as carbon content increased. Both of these properties affect martensite morphology to a large extent.
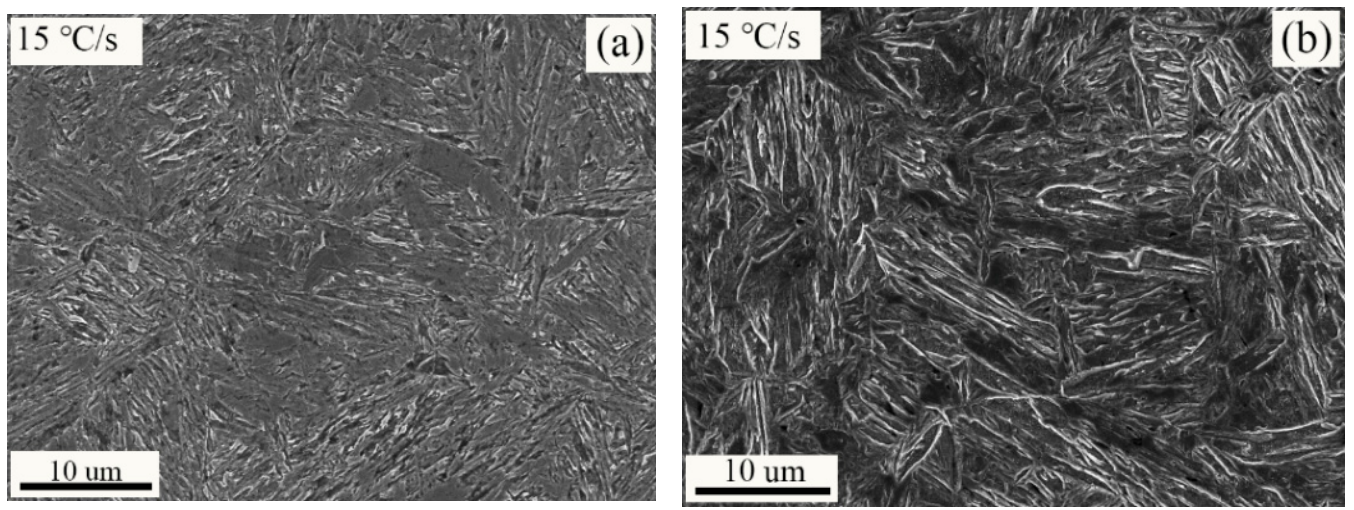

Figure 8. The microstructure of the carburised layer $(\mathbf{a})$, the matrix $(\mathbf{b})$ at a cooling rate of $15^{\circ} \mathrm{C} / \mathrm{s}$. 


\subsection{CCT Diagram Analysis}

The temperature of phase transition was determined via the expansion method. Along with the results of microstructural observation in the previous section, the CCT diagram of both the carburised layer and the $23 \mathrm{CrNi} 3 \mathrm{Mo}$ steel matrix were constructed (Figure 9). The thermal expansion method is commonly used to determine phase transition temperature. This method applies different principles of thermal expansion coefficient and specific volume to determine thermal differences. The specific volume of each phase followed the order of austenite $<$ ferrite $<$ pearlite $<$ bainite $<$ martensite, but the opposite order was observed for the coefficient of thermal expansion. Therefore, in the phase transformation process of steel, ferrite precipitation and austenite decomposition into pearlite, bainite or martensite are all accompanied by volume expansion [18].
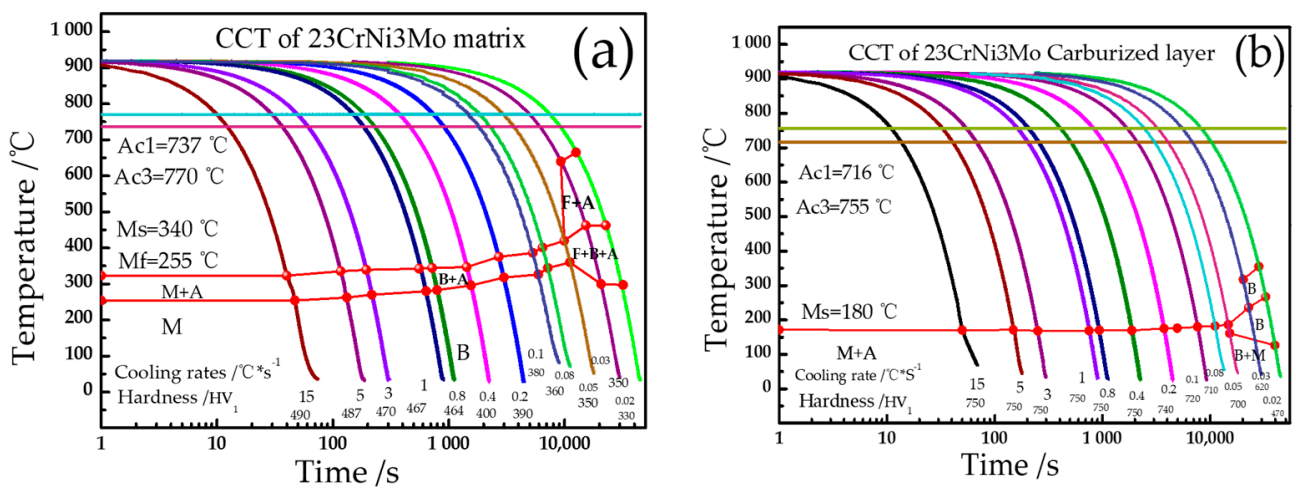

Figure 9. (a) CCT diagram of the matrix, and (b) CCT diagram of the carburised layer.

As one of the most important reference for production, CCT diagrams provide important information for designing heat treatment processes. Figure 9 shown the CCT diagrams of both the carburised layer and the $23 \mathrm{CrNi3Mo}$ steel matrix. During the continuous cooling process, bainite and martensite were found to be the main phase transformation products. Due to the differences in carbon content, their phase transition temperatures and the critical cooling rate of phase transition were vastly different. In the carburised layer, bainite transformation moved to the right owing to its high carbon content, and bainite could only be obtained at cooling rates lower than $0.05^{\circ} \mathrm{C} / \mathrm{s}$. By contrast, in the matrix, bainite transformation occurred within a broader cooling rate range, and the critical cooling rate of martensitic transformation was $0.8^{\circ} \mathrm{C} / \mathrm{s}$. The phase transformation temperatures are listed in Table 2.

Table 2. The phase transition temperature points of the carburised layer and the matrix.

\begin{tabular}{ccccc}
\hline Series & $\mathbf{A c 1} /{ }^{\circ} \mathbf{C}$ & $\mathbf{A c} 3 /{ }^{\circ} \mathbf{C}$ & $\mathbf{M s} /{ }^{\circ} \mathbf{C}$ & Mf $/{ }^{\circ} \mathbf{C}$ \\
\hline carburised layer & 716 & 743 & 180 & - \\
matrix & 757 & 778 & 340 & 255 \\
\hline
\end{tabular}

The Ac1 and Ac3 values of the carburised layer considerably declined compared with those of the matrix (Table 2). Austenite formation is related to carbon atom diffusion [19]. The decline in Ac1 and Ac3 values was primarily caused by the differences in carbon atom diffusion between the carburised layer and the matrix. The carbon content decreased from the surface to the core and, by extension, the diffusion coefficient. Therefore, pushing austenite transformation to a higher temperature. Due to the differences in carbon content, a gradient of austenitizing temperature was observed from the carburised layer to the matrix. The surface layer with a higher carbon content was austenitised in lower temperatures during the heat treatment process, and the surface often reached the predetermined temperature faster than the core (especially for large-sized workpieces). These means that 
during the heat treatment process, the austenitizing time of carburised layer is longer than the subsurface layer and the core of the workpiece.

When the cooling rates higher than $0.05{ }^{\circ} \mathrm{C} / \mathrm{s}$, the endpoint of the martensite transformation (Mf) could not be found in the CCT diagram of the carburised layer (Figure 9b), and volume fraction of RA in the carburised layer was higher than that in the matrix (Figure 10). The increase in carbon content not only caused the Ms point to decrease [18], also makes martensite transition more completes. As the cooling rate further increased, the volume fraction of RA in the carburised layer tended to decrease because of the increase in the driving force for phase transition, which in turn, was caused by the increase in cooling rate. At cooling rates lower than $0.05^{\circ} \mathrm{C} / \mathrm{s}$, the carbon content did not alter the volume fraction of RA in the microstructure.

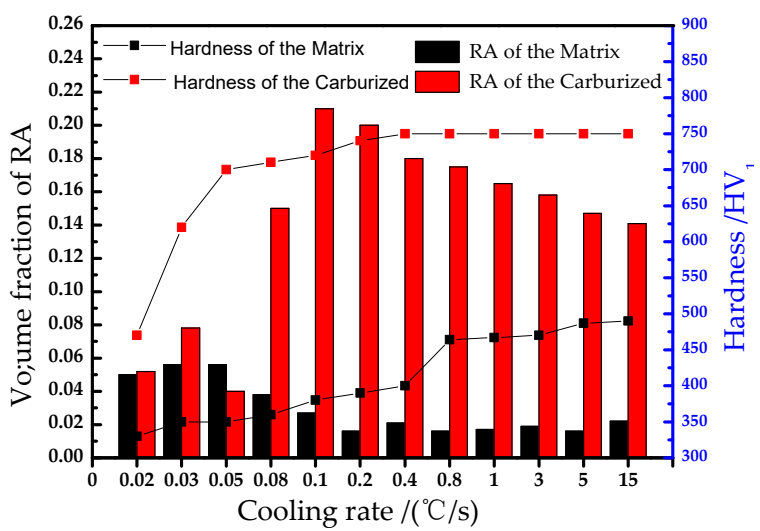

Figure 10. The volume fraction of RA and hardness of the matrix and the carburised layer.

\subsection{Kinetics of Matrix Bainite Transformation}

Figure 11a indicated that the higher the cooling rate was, the lower the starting temperature of bainite transformation would be. This was because the nucleation rate of bainite is affected by atom diffusion at $\gamma$-grain boundaries. Growth rate is affected by the diffusion rate of $C$-atom from the $\gamma$-side of the $\gamma$-bainite interface to the $\gamma$-phase far away from the interface [20]. The main factor that affects $C$ atom diffusion is undercooling, which depends on the cooling rate. A faster cooling rate leads to greater undercooling and stronger driving force of phase transformation; hence, phase transformation is easier at low temperatures. Sung et al. [21] proposed that the different microstructural characteristics of bainite may be attributed to differences in phase transformation temperatures. The present study also investigated the bainite transformation kinetics of the $23 \mathrm{CrNi} 3 \mathrm{Mo}$ steel matrix by exploring the mechanism of nucleation and growth mode of bainite under different cooling rates.
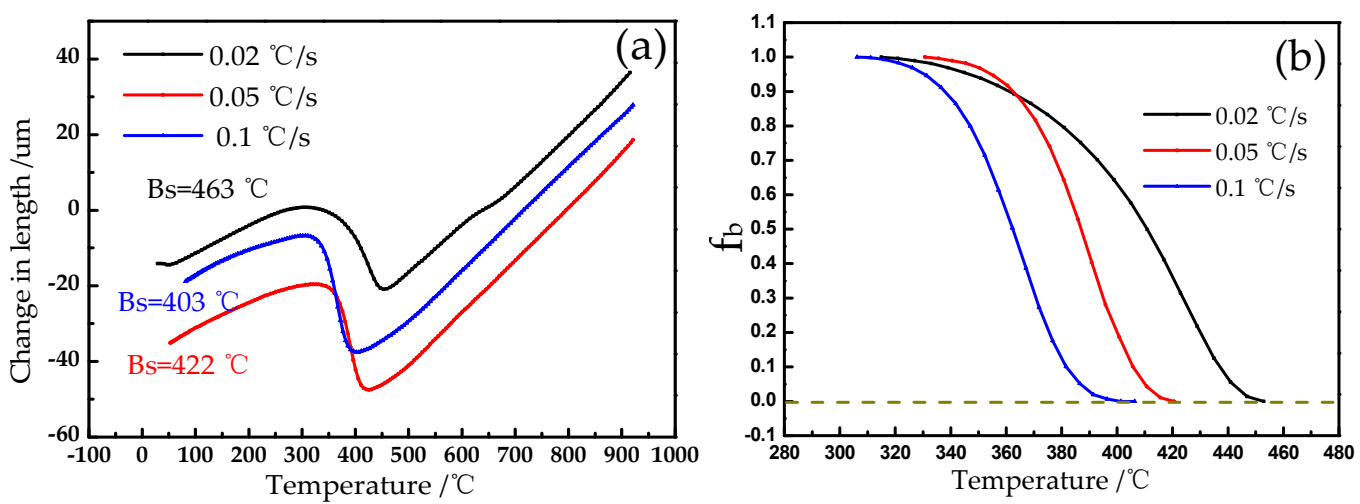

Figure 11. (a) The cooling curves of the matrix, and (b) the relationship between bainite transformed volume fraction and temperature at $0.02{ }^{\circ} \mathrm{C} / \mathrm{s}, 0.05^{\circ} \mathrm{C} / \mathrm{s}$ and $0.1^{\circ} \mathrm{C} / \mathrm{s}$ cooling rate. 
The bainite transformation is a complicated process accompanied by nucleation and growth [22]. During continuous cooling, the particular activation energy for each transformed volume fraction $\left(f_{b}\right)$ may inconsistent, this is different from isothermal process. The activation energy corresponding to a fixed $\mathrm{f}_{\mathrm{b}}$ was used to describe the variable activation energy, calculated by a Kissinger analysis [23,24],

$$
\ln \left(\frac{\mathrm{T}_{\mathrm{f}_{\mathrm{b}}}^{2}}{\varphi}\right)=\frac{\mathrm{E}_{\mathrm{f}_{\mathrm{b}}}}{\mathrm{RT}_{\mathrm{f}_{\mathrm{b}}}}+\mathrm{C}
$$

where $T_{\mathrm{f}_{\mathrm{b}}}$ is the temperature corresponding to the Bainite transformation volume fraction, $\varphi$ is the cooling rate, $\mathrm{E}_{\mathrm{f}_{\mathrm{b}}}$ is the activation energy, $\mathrm{R}$ is the gas constant and $\mathrm{C}$ is constant. The activation energy $\left(\mathrm{E}_{\mathrm{f}_{\mathrm{b}}}\right)$ is regarded as the slope of the straight line in a plot between $\ln \left(\frac{\mathrm{T}_{\mathrm{f}_{\mathrm{b}}}^{2}}{\varphi}\right)$ and $1 / \mathrm{T}_{\mathrm{f}_{\mathrm{b}}}$. The local activation energy for each $\mathrm{f}_{\mathrm{b}}$ can be obtained on the basis of the diatometric data (Figure 11b), Figure 12a shown the local activation energy for each $f_{b}$ at different cooling rates, indicates that the bainite transformation becomes easier with the increasing of its volume fraction and cooling rate.
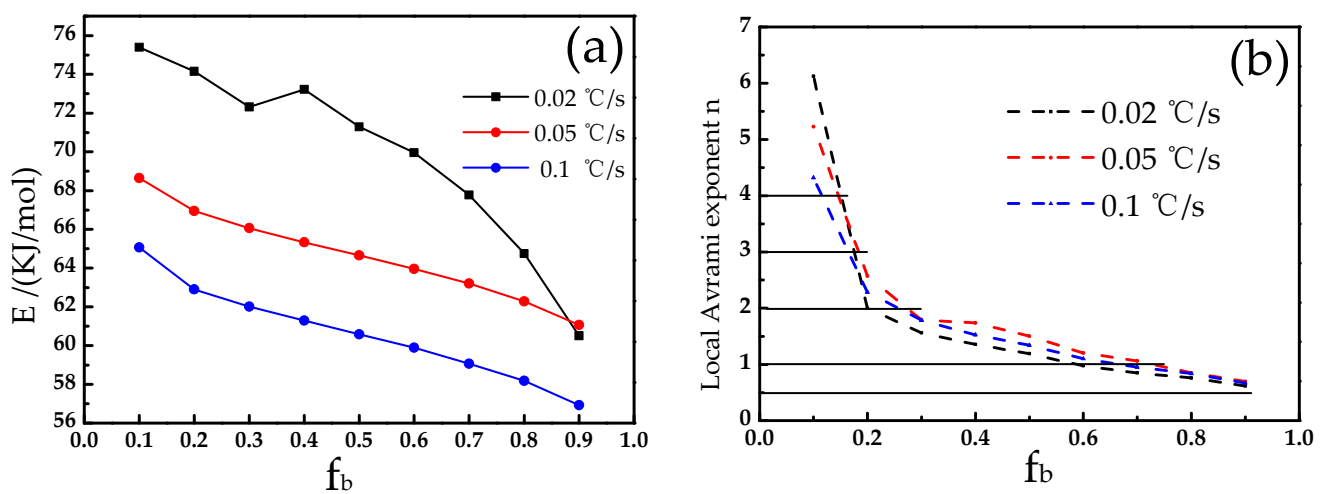

Figure 12. (a) Relationship between local activation energy and volume fraction of bainite transformation, (b) relationship between local Avrami exponent and the bainite transformed volume fraction.

The bainite transformation Kinetics under non-isothermal conditions has been modeled by the modified Johnson-Mehl-Avrami (JMA) equation, which is expressed as follows [24-26],

$$
\mathrm{f}_{\mathrm{b}}=1-\exp \left((-\mathrm{kt})^{\mathrm{n}}\right)=1-\exp \left\{-\left[\frac{\mathrm{k}\left(\mathrm{T}-\mathrm{T}_{0}\right)}{\varphi}\right]^{\mathrm{n}}\right\}
$$

where $\mathrm{T}$ is the temperature at a fixed state of transformation, $\mathrm{T}_{0}$ is the onset temperature of bainite transformation, $\mathrm{n}$ is the Avrami exponent, and $\mathrm{k}$ is a new frequency factor that can be expressed as,

$$
\mathrm{k}=\mathrm{k}_{0} \exp \left(-\frac{\mathrm{E}}{\mathrm{RT}}\right)
$$

where $\mathrm{k}_{0}$ is a constant. The JMA equation can be simplified to obtain Equation (4) [27]:

$$
\mathrm{n}=-\frac{\mathrm{R} \partial \ln \left[-\ln \left(1-\mathrm{f}_{\mathrm{b}}\right)\right]}{\mathrm{E}_{\mathrm{f}_{\mathrm{b}}} \partial(1 / \mathrm{T})} .
$$

Avrami exponent $\mathrm{n}$ is widely used to reflects the phase transition mechanism. The dilatometric curves in Figure 11a were processed to obtain the $f_{b}-T$ curve (Figure 11b). The dynamic data were fitted using the Origin software, with $1 / \mathrm{T}$ as the abscissa and $\ln \left[-\ln \left(1-f_{b}\right)\right]$ as the ordinate, and the slope is $n E / R$. Finally, the Avrami exponent $n$ at the three cooling rates were derived (Figure 12b).

The new crystal nucleus at the grain boundary is restricted by adjacent crystal grains, and the edge cannot extend forward. Therefore, they can only grow in the direction 
perpendicular to the grain interface along the one-dimensional mode. When new crystal nuclei grow along the axis direction of the crystal edges, the growth also be limited by the adjacent grains and follow the two-dimensional mode. New crystal nuclei at crystal corners will grow without restriction in any direction, and the growth model is three-dimensional model [23].

As shown in Figure $12 \mathrm{~b}$, when $0<\mathrm{f}_{\mathrm{b}}<0.2, \mathrm{n}$ is larger than 4 , which is anomalous and has no physical meanings for bainite nucleation and growth $[26,28]$. When $0.2<\mathrm{f}_{\mathrm{b}}<0.8$, Avrami exponent $\mathrm{n}$ lies between 0.5 and 3, indicated that the mian mechanism of bainite transformation of the 23CrNi3Mo steel matrix is two-dimensional growth and one-dimensional growth.

\section{Conclusions}

In this study, the phase transformation behaviour of the carburised layer and the matrix of $23 \mathrm{CrNi3Mo}$ steel was comparetively investigated. The continuous cooling transformation (CCT) diagram, the volume fraction of retained austenite (RA) and dilatometric curves of both the carburised layer and the matrix were obtained. The main conclusions were drawn as follows:

(1) The critical temperatures (Ac1, Ac3, Ms and Mf) of the matrix were as follows: Ac1 $=737^{\circ} \mathrm{C}, \mathrm{Ac} 3=770{ }^{\circ} \mathrm{C}, \mathrm{Ms}=340^{\circ} \mathrm{C}, \mathrm{Mf}=255^{\circ} \mathrm{C}$. However, unlike those of the matrix, all of the critical temperatures of the carburised layer decreased as follows: Ac1 $=716^{\circ} \mathrm{C}$, Ac3 $=755^{\circ} \mathrm{C}$, Ms $=180{ }^{\circ} \mathrm{C}$.

(2) The main products of undercooled austenite transformation were bainite and martensite microstructures. The critical cooling rate of martensite transformation of the carburised layer and the matrix was $0.05^{\circ} \mathrm{C} / \mathrm{s}$, and $0.8^{\circ} \mathrm{C} / \mathrm{s}$, respectively. The lamellar martensite of the carburised layer was finer than the lath martensite of the matrix.

(3) During the cooling process at low cooling rates, the volume fraction of RA in both matrix and the carburised layer were almost the same. However, as the cooling rate was more than $0.08^{\circ} \mathrm{C} / \mathrm{s}$, the volume fraction of RA in the carburised layer is higher than that of matrix.

(4) The main mechanisms of bainite transformation of the 23CrNi3Mo steel matrix are two-dimensional growth and one-dimensional growth.

Author Contributions: Conceptualization, methodology, M.L.; validation, C.H.; investigation, W.S.; data curation, W.S.; writing-original-draft preparation, W.S.; writing-review and editing, W.S. and M.W.; visualization, C.H. and M.L.; All authors have read and agreed to the published version of the manuscript.

Funding: This research was funded by Guizhou Science and Technology Plan Project (Grant No. GY [2012]3044) and Achievement Transformation Program (2019-4024) of Guizhou Science and Technology Department, Guizhou Province.

Institutional Review Board Statement: Not applicable.

Informed Consent Statement: Informed consent was obtained from all subjects involved in the study.

Data Availability Statement: The data presented in this study are available on request from the corresponding author.

Conflicts of Interest: The authors declare no conflict of interest.

\section{References}

1. Huang, Y.; Cheng, G.G.; Xie, Y. Modification Mechanism of Cerium on the Inclusions in Drill Steel. Acta Metall. Sin. 2018, 54, $1253-1261$.

2. Huang, Y.; Xie, Y.; Cheng, G.G. Comparing cleanliness of 23CrNi3Mo hollow drills steel at home and abroad. Zhongguo Youse Yejin 2018, 28, 10-16.

3. Huang, B.; Liu, Y.Z.; Zhou, L.Y.; Li, G.W.; Zhang, D. Research on Fatigue Fracture Defect of 23CrNi3Mo Drill Steel. Adv. Mater. Res. 2011, 314-316, 1955-1959. [CrossRef]

4. Yan, Y.M. Effect of cooling method on microstructure of 23CrNi3Mo carburized steel. Heat Treat. Met. 2016, 41, 134-138. 
5. Jiang, B.; Liu, Y.Z.; Zhou, L.Y.; Zhang, C.L.; Chen, L.; Wang, G.C. Research Status of Microstructure and Properties Control of Steel for Heavy Drill. Mater. Rep. 2019, 33, 854-861.

6. Akita, M.; Tokaji, K. Effect of carburizing on notch fatigue behaviour in AISI 316 austenitic stainless steel. Surf. Coat. Technol. 2006, 200, 6073-6078. [CrossRef]

7. Wei, Y.; Xie, B.S.; Wang, B.; Cai, Q.W.; Xu, S.X. Effect of Rolling process on Microstructure and Properties of 95CrMo Drill Steel. J. Iron Steel Res. Int. 2016, 23, 910-916. [CrossRef]

8. Kenan, G.; Mehmet, D. Effect of case depth on fatigue performance of AISI 8620 carburized steel. Int. J. Fatigue 1999, 21, 207-212.

9. Jiang, B.; Mei, Z.; Zhou, L.-Y.; Liu, G.-L.; Wang, Z.-L.; Huang, B.; Liu, Y.-Z. High toughness and multiphase microstructure transition product of carburizing steel by a novel heat treatment cooling process. Mater. Sci. Eng. A 2016, 675, 361-370. [CrossRef]

10. Xiao, N.; Hui, W.; Zhang, Y.; Zhao, X.; Chen, Y.; Dong, H. High cycle fatigue behavior of a low carbon alloy steel: The influence of vacuum carburizing treatment. Eng. Fail. Anal. 2020, 109, 104215. [CrossRef]

11. Cao, Z.; Liu, T.; Yu, F.; Cao, W.; Zhang, X.; Weng, Y. Carburization induced extra-long rolling contact fatigue life of high carbon bearing steel. Int. J. Fatigue 2020, 31, 105351. [CrossRef]

12. Fang, Y.; Chen, X.; Madigan, B.; Cao, H.; Konovalov, S. Effects of strain rate on the hot deformation behavior and dynamic recrystallization in China low activation martensitic steel. Fusion Eng. Des. 2016, 103, 21-30. [CrossRef]

13. Wang, B.X.; Zhou, C.L.; Liu, X.H.; Wang, G.D. Effect of deformation conditions on continuous cooling transformation of a Mn-Cr gear steel. Acta Metall. Sin. 2005, 41, 511-516.

14. Wang, Y.; Yang, Z.; Zhang, F.; Qin, Y.; Wang, X.; Lv, B. Microstructures and properties of a novel carburizing nanobainitic bearing steel. Mater. Sci. Eng. A 2020, 777, 139086. [CrossRef]

15. Liu, J.; Li, M.; Zhang, P.; Zhu, Y.; Li, S. Experiment research on the transformation plasticity by tensile/compressive stress and transformation kinetics during the martensitic transformation of 30Cr2Ni4MoV steel. Mater. Res. Express 2020, 6, 1265g8. [CrossRef]

16. Qiao, Z.X.; Liu, Y.C.; Yu, L.M.; Gao, Z.M. Formation mechanism of granular bainite in a 30CrNi3MoV steel. J. Alloys Compd. 2009, 475, 560-564. [CrossRef]

17. Wang, Y.; Yang, Z.; Zhang, F.; Wu, D. Microstructures and mechanical properties of surface and center of carburizing 23Cr2Ni2Si1Mo steel subjected to low-temperature austempering. Mater. Sci. Eng. A 2016, 670, 166-177. [CrossRef]

18. Manuel, G.; Lucía, R.; Esther, E.; Sebastian, F.M. Phase Transformation under Continuous Cooling Conditions in Medium Carbon Microalloyed Steels. J. Mater. Sci. Technol. 2014, 30, 511-516.

19. Cerda, F.C.; Sabirov, I.; Goulas, C.; Sietsma, J.; Monsalve, A.; Petrov, R. Austenite formation in $0.2 \%$ C and $0.45 \%$ C steels under conventional and ultrafast heating. Mater. Des. 2017, 116, 448-460. [CrossRef]

20. Quidorta, D.; Brechet, Y. The role of carbon on the kinetics of bainite transformation in steels. Scr. Mater. 2002, 47, 151-156. [CrossRef]

21. Sung, H.K.; Shin, S.Y.; Hwang, B.; Lee, C.G.; Kim, N.J.; Lee, S. Effects of Rolling and Cooling Conditions on Microstructure and Tensile and Charpy Impact Properties of Ultra-Low-Carbon High-Strength Bainitic Steels. Metall. Mater. Trans. A 2010, 42, 1827-1835. [CrossRef]

22. Kempen, A.T.W.; Sommer, F.; Mittemeijer, E.J. The isothermal and isochronal kinetics of the crystallization of bulk amorphous Pd $40 \mathrm{Cu} 30$ P 20 Ni 10. Acta Mater. 2002, 50, 1319-1329. [CrossRef]

23. Gupta, C.; Dey, G.K.; Chakravartty, J.K.; Srivastav, D.; Banerjee, S. A study of bainite transformation in a new CrMoV steel under continuous cooling conditions. Scr. Mater. 2005, 53, 559-564. [CrossRef]

24. Zheng, Y.F.; Wu, R.M.; Li, X.C.; Wu, X.C. Continuous cooling transformation behavior and bainite formation kinetics of new bainitic steel. Mater. Sci. Technol. 2017, 33, 454-463. [CrossRef]

25. An, F.C.; Zhao, S.X.; Xue, X.K.; Wang, J.J.; Yuan, G.; Liu, C.M. Incompleteness of bainite transformation in quenched and tempered steel under continuous cooling conditions. J. Mater. Res. Technol. 2020, 9, 8985-8996. [CrossRef]

26. Zhang, Z.M.; Cai, Q.W.; Yu, W.; Li, X.L.; Wang, L.D. Continuous Cooling Transformation Behavior and Kinetic Models of Transformations for an Ultra-Low Carbon Bainitic Steel. J. Iron Steel Res. Int. 2012, 19, 73-78. [CrossRef]

27. Lu, W.; Yan, B.; Huang, W.H. Complex primary crystallization kinetics of amorphous Finemet alloy. J. Non Cryst. Solids 2005, 351, 3320-3324. [CrossRef]

28. Hui, Q.; Xue, X.; Kou, H.; Lai, M.; Tang, B.; Li, J. Kinetics of the $\omega$ phase transformation of Ti-7333 titanium alloy during continuous heating. J. Mater. Sci. 2012, 48, 1966-1972. [CrossRef] 